\title{
Adoption of Coffee Shade Agroforestry Technology and Shade Tree Management in Gobu Seyo District, East Wollega, Oromia
}

\author{
Tolera Urgessa Waktola $\mathbb{D}^{1}$ and Kidist Fekadu $\mathbb{D}^{2}$ \\ ${ }^{1}$ Self Help Africa Ethiopian Office, Addis Ababa, Ethiopia \\ ${ }^{2}$ Hawassa University Wondo Genet College of Forestry and Natural Resources, Wondo Genet, Ethiopia \\ Correspondence should be addressed to Kidist Fekadu; kidistfekadukf@gmail.com
}

Received 21 May 2019; Revised 17 March 2021; Accepted 4 June 2021; Published 8 July 2021

Academic Editor: Volkan Okatan

Copyright (C) 2021 Tolera Urgessa Waktola and Kidist Fekadu. This is an open access article distributed under the Creative Commons Attribution License, which permits unrestricted use, distribution, and reproduction in any medium, provided the original work is properly cited.

\begin{abstract}
Coffee production in the form of agroforestry practices is the most important management approach to improve the livelihoods of the farming community. This study was conducted to assess factors affecting the adoption of the technology, its socioeconomic and environmental benefits, and the management practices related to the technology. Out of eight kebeles in the district, two kebeles were selected purposively based on the existing and extensive agroforestry practices. Four villages were selected randomly. Based on the preidentified criteria as coffee growers and nongrowers, coffee growers were selected purposively. Then a total of 120 households were selected by Simple Random Sampling Method. Data were collected by using structured interview and field observation. The data were analyzed by using descriptive statistics analysis. The logit model was used to identify the factors affecting the adoption of coffee shade agroforestry technology. The results of this study showed that adoption of coffee shade agroforestry technology had a positive relationship and was statistically significant at $1 \%$ level with age and area covered by coffee production, while household composition and training were at $5 \%$ level. Education level, land holding, and extension services also had positive relationship, but it was not statistically significant. The farmers in the study area mentioned other benefits of these technologies such as for animal feed, firewood and construction materials, medicinal purpose, erosion control, honey bee production, and soil fertility enhancement. Different management activities were also identified in the area (such as composting, pruning, watering, and weeding). Coffee shade agroforestry technology was important to diversify the agricultural products, to solve the problem of livelihood, and adds economic and environmental benefits.
\end{abstract}

\section{Introduction}

1.1. Background. Coffee is shade-tolerant plant and is mainly grown under shade trees in complex agroforestry systems. Agroforestry technologies range from traditional to recent practices such as taungya, home gardens, improved fallows, multipurpose trees, plantation-crop alley cropping, and others [1]. Specifically coffee shade agroforestry technology is a traditional and complex agroforestry system, where coffee is associated with various other species in different storeys (or "levels"). This provides ecologically and economically sustainable use of natural resources. According to Ehrenbergerová et al. [2], coffee is a shadeloving plant and the shade trees reduce the stress of coffee
(Coffea spp.) by ameliorating adverse climatic conditions and nutritional imbalances. Recha et al. [3] added that coffee agroforestry technology has many benefits in the economy and supports the households' needs of medicine and timber. Soil fertility will be improved by the agroforestry practices, especially when nitrogen-fixing plants are added to the production system. The trees also contribute to the reduction of soil erosion and to the carbon sequestration.

Shade trees in coffee agroforestry system also increase and preserve surface soil humidity and reduce the direct light intensity reaching the coffee plant, which has a principal role towards amplified production of coffee. Growing coffee under shade trees is essential not only for the sustenance of coffee plantations but also for protecting the 
environment in the ecologically delicate regions [4]. Lin et al. [5] reported that shade tree is essential to protect the coffee from climate extremes and water loss in the future. Higher quality of coffee beans is produced in Costa Rica, where Arabica coffee is grown under shade [6]. Moreover, shade trees have a role in reducing the vulnerability of households to climatic stress, pest outbreaks, falling prices/crop insurance, and food insecurity [7]. The reduction of pest abundance in shade coffee attributed to habitat complex leads to better pest control [8]. Dahlqvist [9] reported that coffee production under shade is exercised to produce coffee in a sustainable way and with least inputs of agrochemicals.

Although coffee is a shade-loving plant, it is possible to grow coffee without shade at optimal sites and with high agrochemical inputs. However, currently, such coffee shade agroforestry system got an attention by many countries because of coffee plant sensitivity to climate change and variability and also due to increasing health and environmental consciousness of people.

Adoption of different agroforestry technologies is influenced by different factors including socioeconomic, environmental, and mental processes that are governed by a set of intervening variables. Those variables include individual needs, awareness about the technology, and individual perceptions about methods used to achieve those needs [10]. Gender is also an essential variable in decisionmaking when adopting new agroforestry technologies $[11,12]$; there is a higher likelihood of adopting high value agroforestry (HVAF) through planting tree species with timber and fruit effectiveness. Gebrelibanos [13] and Mume [14] have recognized that adoption of agricultural innovations decisions of farmers is influenced by socioeconomic, institutional, demographic, and physical characteristics.

1.2. Statement of the Problem. Most Ethiopian coffee plants grow understory of evergreen natural forest and undermanaged agroforestry systems. Gobu Seyo district is in the East Wollega Zone in Ethiopia, where traditional coffee production is taking place. Coffee shade tree agroforestry practice traditionally exists at the area of coffee production system owned by many local coffee producing small-scale farmers in the study area. A lot of effort has been done since 2006 to improve its contribution to sustainable coffee production by selecting the best coffee shade tree and by introducing shade tree management techniques. In spite of its importance and the effort made by the government, there has been increasing destruction on the tree reserve due to high demand of forest products and such high deforestation rates had an impact on climate variability and detrimental effect on coffee production practice. Shade tree provides the right conditions for successful cultivation of coffee, by reducing light intensity and soil temperatures, increasing humidity, and preserving soil moisture. Prevention and rehabilitation of shade tree loss are a key issue that needs special consideration.

The success of any technology depends on its dissemination among the prospective users, which is finally measured by the level of adoption of that technology. It is to be predictable that certain sustainable development can take place if the technology can be transferred properly. Although the strategy is launched to the area, many farmers do not adopt it fully and there are no systematic studies on coffee shade tree plantation and management practices. This study well thought of the factors that affect planting shade trees, potential benefits, and management practices of coffee shade agroforestry technology in the district.

\subsection{Objectives}

1.3.1. General Objective. The objective of the study was to investigate the adoption of coffee shade agroforestry technology and shade tree management practices by smallholder coffee producers in Gobu Seyo district.

\subsubsection{Specific Objectives}

(i) To assess the role of socioeconomic characteristics of the household for coffee shade agroforestry technology adoption

(ii) To examine other roles of shade trees such as environmental, economic, and social roles

(iii) To assess shade tree management practices in the study area

\subsection{Research Questions}

(i) Is the coffee shade agroforestry technology adoption affected by socioeconomic characteristics of the HHs?

(ii) Do coffee shade trees have social, economic, and environmental values other than shading value?

(iii) What types of shade tree management practices are applied in the area?

1.5. Significance of the Study. Coffee production dominates agriculture sector of Ethiopia in its contribution to foreign exchange and the national economy of commodity exchange [15]. Coffee also directly supports the livelihoods of more than $25 \%$ of the population in the country and is at the center of social and family life. More than $70 \%$ of global coffee is cultivated by smallholder growers in Africa, Asia, and the Americas with many of them relying on coffee as their major source of income [16]. In Ethiopia, from 1960 to 2006, mean annual temperature increased by $1.3^{\circ} \mathrm{C}$ [17]. Nowadays, the impact of climate variability and change is adversely affecting coffee production. The majority of Ethiopia's coffee is grown on 4 million smallholder farms. Many farmers do not have the money or resources to adapt to the changing climate. The traditional shade coffee agroforestry system is the best way to mitigate the climate impact in such resourcepoor farmers, specifically the case of Ethiopia. Therefore, trying to search for the best way of doing it will contribute a lot to its better contribution and also to convincing farmers. Others also predict reduction in areas suitable for coffee production by 2050 due to climate change. To that end, such 
a research on coffee shade tree agroforestry technology is a very important and urgent solution to provide realistic information to formulate policies and develop intervention mechanisms to the study area. This study also identified the factors that delay the adoption of coffee shade agroforestry technology. Therefore, the findings of this study enable the planners and extension workers in planning and implementation of programs to implement better shade coffee agroforestry technology that fits Gobu Seyo district.

\section{Materials and Methods}

2.1. Description of the Study Area. Gobu Seyo is one of the districts in the East Wollega Zone, which is located in the eastern part of the zone. Today, this district is subdivided into eight kebele administrations and one city center for all its administrative purposes. Anno is the capital town of the district located on the main road along with Addis at the distance of $265 \mathrm{~km}$ and it is located at about 65 kilometers to the east of the zonal city, Nekemte, having a total area of $383.80 \mathrm{~km}^{2}$. Gobu Seyo is located at $36^{\circ} 53^{\prime} 11^{\prime \prime}$ to $37^{\circ} 03^{\prime} 06^{\prime \prime}$ east longitude and $9^{\circ} 01^{\prime} 01^{\prime \prime}$ to $9^{\circ} 20^{\prime} 33^{\prime \prime}$ north latitude. This district is adjoining with Bako Tibe district of West Shewa Zone in the east, Gudeya Bila district in the north, Boneya Boshe district in the south, and Sibu Sire district in the west. According to the Gobu Seyo agricultural office, the district is divided into two distinct geographical areas with different proportions, namely, the midland, $79.99 \%$, having 6 rural peasant associations, and the low land, $20.01 \%$, with 2 rural peasant associations. The general altitude range of the district is $1500 \mathrm{~m}$ to $1960 \mathrm{~m}$ above sea level; see Figure 1 .

2.1.1. Climate. Most parts of the district are characterized by subhumid climatic conditions with a mean annual temperature between $13^{\circ} \mathrm{C}$ and $27^{\circ} \mathrm{C}$ and mean annual rainfall of $830 \mathrm{~mm}$ to $1,658 \mathrm{~mm}$ (Gobu Seyo agricultural office).

2.1.2. Soils. Nitisols are the most important soil in the area covering a high amount of the total cultivated land in the area. It is developed on the flat to moderately steep lower foot slope, with a slope gradient of 2 to $18 \%$, which are marked by depth, porous solum, being well drained, and easiness to plow. Vertisols represent another of the most important soils in the area. Vertisols developed on flat to very slopping of the toe slope and found in the slope gradient of 3 to 16 percent $[18,19]$.

2.1.3. Population. The counted population of the district based on the population and housing census conducted in 2007 is 23,993 males, 31,433 females, with a total of 55,426. During this year, about $87.97 \%$ of the total populations are rural populations that are directly engaged in agriculture. The total HH of the district is 6309: $83.8 \%$ male-headed and 16.2\% female-headed (Gobu Seyo agricultural office).

2.2. Sampling Techniques. This study relied on mixedsampling techniques (purposive sampling and random sampling methods). In the first stage, two peasant association (PA)/kebeles (the kebele is the smallest administrative level in the country), Sombo Kejo and Tibe Hara, were selected purposively based on their coffee production potential. In the second stage, four villages, Haro Boro and Adami Kejo from Sombo Kejo kebele and Tibe and Meti Kora from Tribe Hara kebele, were selected randomly. In the third stage, farmers having coffee farms were selected purposively from the selected villages and the sample size was determined by using formula (1). Finally, a total of 120 households $(\mathrm{HH})$ were selected from those villages proportionally as indicated in Table 1 [20].

$$
n=\frac{z^{2} \mathrm{pq} N}{e^{2}(N-1)+z^{2} \mathrm{pq}},
$$

where $n$ is sample size, $N$ is total number of HHs growing coffee in the selected kebeles, $p$ is proportion in the target population $(p=0.5), q=1-p(1-0.5=0.5), e$ is marginal error considered as $5 \%$ for this study, and $z$ is confidence level at $95 \%(\mathrm{Z} \alpha / 2=1.96)$.

2.3. Data Collection Methods. The study was based on a household survey and field observation conducted from December 2017 to February 2018.

2.3.1. Field Observation. The inspection was carried out in the selected villages to assess the existing situation of agroforestry systems and technologies adopted and to observe various tree species and their management techniques integrated by farmers in their farmland and coffee farming system and around their homes. Observations were to validate the collected information during the household questionnaire.

2.3.2. HH Interview. To generate both qualitative and quantitative data, sampled $\mathrm{HHs}$ were interviewed individually using a structured questionnaire. The questionnaire for the survey of households includes the information on household characteristics (age, sex, education level, family size, and landholding size), types of shade trees adopted, time of adoption, socioeconomic and environmental benefits of shade trees, extension activities, and others as indicated in. The data was collected by the researcher himself and enumerators (three diploma holders) after they have been given an explanation and orientation. The questionnaire was translated into the local language, Afan Oromo, for easy understanding and pretested on about 5 farmers who were not considered as respondents in the main survey.

2.4. Methods of Data Analysis. The collected data was coded and filled into Statistical Package for the Social Sciences (SPSS) version 20. Logit regression was used to identify the effects of socioeconomic characteristics of the sampled HHs on the adoption of coffee shade agroforestry technology. $X^{2}$ was used to figure out the difference between adopters and nonadopters and the differences in management activities. 


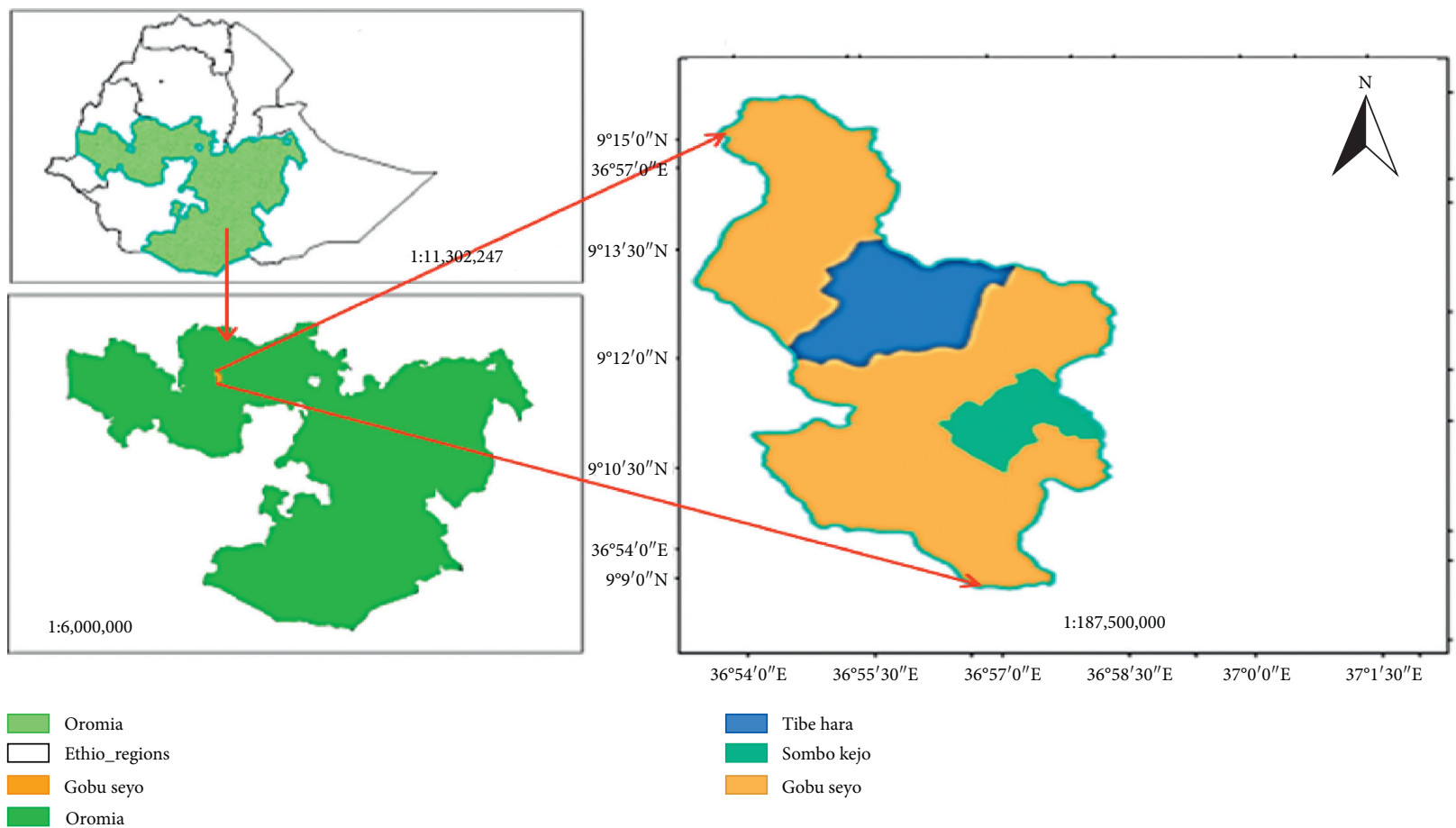

FIGURE 1: Map of study area.

TABle 1: Proportional sample sizes and total HHs of coffee growers in the villages.

\begin{tabular}{lccrr}
\hline Name of villages & Total HHs & No. of coffee grower HHs & Sample size & \% \\
\hline Haro Boro & 139 & 87 & 23 & 26 \\
Meki Bafano & 179 & 99 & 37 & 26.4 \\
Tibe & 233 & 151 & 34 & 24.5 \\
Meti Kora & 246 & 139 & 120 & 24.5 \\
Total & 797 & 476 & 25.2 \\
\hline
\end{tabular}

Descriptive statistics, such as mean, frequency, cross-tabulation, and percentage, were also used.

\subsection{Model Specification and Description of Variables.} Several adoption studies in the past have widely used dichotomous choice data models such as logit and probit in trying to determine the probability of adoption and its determinants such as socioeconomic and household characteristics [21-23]. This is because they allow for a more detailed analysis of farmers' adoption decisions on a single technology $[24,25]$. Currently, there is a need for the adoption of coffee shade agroforestry technologies as a package, hence the need for analysis using the count data model. Given the assertion that over time there are more than just two identified groups (adopters and nonadopters), it is possible to have a more refined distinction of adopters. Both the logit and probit analyses specify a functional relationship between the probability of adoption and various explanatory variables [26]. To generate talented bordered probabilities within zero to one interval, a logistic cumulative distribution function was realized to apply a logit model. Like log linear regression, logistic regression is based on probabilities and odds ratios. In the case of the logit model, the odds ratio is defined as the ratio of the odds of being classified in one category of the dependent variable for the two different values of the dependent variable. The ordered logit model recognizes unequal differences between ordinal categories in the dependent variables. That is, given a unit change in a descriptive variable, the model captures the qualitative differences between adopters and nonadopters of coffee shade agroforestry technology used, hence accounting for the categorical nature of dependent variables as well as their ordinal nature.

The dependent variable in the observed estimation is the choice of planting a coffee shade tree. While farmers adopt a coffee shade agroforestry technology, several factors can influence their decision to aspire in a technology. This section has identified the variables which determine the adoption of various technologies using binary logistic regression (Table 2). The choice of the descriptive variables is based on accessible data. The descriptive variables included household characteristics such as gender, age, education level, household size, total farm size, and area covered by coffee; institutional factors such as training and extension services were hypothesized to influence the adoption of coffee shade agroforestry technology. Of these eight variables, three were dummy and five categorical were included 
TABLE 2: Relationship of training given and decided to plant shade trees $(n=120)$.

\begin{tabular}{lccc}
\hline & \multicolumn{3}{c}{$\begin{array}{c}\text { Have you ever } \\
\text { participated in any type } \\
\text { of coffee production } \\
\text { training program? }\end{array}$} \\
& No & Yes & Percent \\
\hline Coffee nursery management & 0 & 10 & 8.3 \\
Coffee production and management & 0 & 65 & 54.2 \\
Coffee seed preparation & 0 & 12 & 10 \\
Coffee processing and marketing & 0 & 18 & 15 \\
No training & 15 & 0 & 12.5 \\
\hline
\end{tabular}

in the model. Table 3 gives the descriptions and nature of the variables used for the judgment. Likewise, the hypothesis of how the variables influence the adoption of planting coffee shade agroforestry technology is presented in the next chapter.

\subsection{Interpretation of Results of the Logistic Regression} Analysis. Interpretation of the logistic regression results follows those of [27, 28], Hair Jr. et al. [29], and Pallant [30-33]. It focuses on the Wald test, coefficients, and odds ratios. The Wald test is one of the simplest ways of evaluating the contribution of individual coefficients/predictors to a model [34]. The Wald statistics are used to test the significance of individual coefficients in the model (Bewick et al., 2005; [29, 34]) if a good enough model is found [34]. The Wald statistic provides the statistical significance for each estimated coefficient for hypothesis testing to occur [35]. The Wald statistic tells us whether the $\beta$ coefficient for the predictor is significantly different from zero [36]. Each Wald statistic is compared with a distribution with 1 degree of freedom (Bewick et al., 2005). Coefficients that are significantly different from zero indicate that the predictor is making a significant contribution to the prediction of the outcome (Y) [36].

Logistic regression tests the hypothesis that a coefficient is different from zero [35]. The coefficients (B) for the predictors are the natural logs of the odds ratio $\exp$ (B) [34]. The sign of the coefficient indicates whether it is increasing or decreasing as $x$ increases [33]. Although the coefficients are similar to the odds ratio, the odds ratio is favored, because it does not require a logarithmic transformation and is easier to understand [36].

\section{Results and Discussion}

3.1. Basic Household Sociodemographic Characteristics. In this study, the age of the respondents lies in the range of $30-50$. The majority $(80 \%)$ of the HHs in the area were maleheaded. In general, $75.8 \%$ of the sampled HHs were educated and only $24.2 \%$ were not educated. The average family size of the respondents in the area is 4.87 and almost all of the respondents $(96.7 \%)$ were married (Table 4$)$. The average landholdings of the farmers in the study area were 2.43 ha.
Concerning coffee area coverage, the maximum area covered by coffee was 1 hectare and the minimum is 0.015 hectares. The average area coverage is 0.28 hectares. This area coverage has a direct relationship with the total landholding of the farmers. Relatively respondents having a large hectare of total farming land have large coffee areas (Table 4).

\subsection{Factors Affecting Adoption Decision of the Farmers.} Sex of the household head was found to be negatively influencing the decision of $\mathrm{HH}$ to adopt coffee shade agroforestry technology. The result indicated that if the household head is male, the chances of adoption of coffee shade tree decrease by the factor of 0.48 as compared to female-headed, but the result was not statistically significant (Table 5).

The effect of the age of household head on the adoption of coffee shade agroforestry technology was statistically significant at the $1 \%$ level (Table 5). The result revealed that as the age of the $\mathrm{HH}$ head increases the chance of adoption of the technology increases by a factor of 29.75; other factors remained constant. This implies that the older generation is more likely adopters of coffee shade agroforestry technology package as compared to younger farmers (Table 5). The reason could be the opportunity of getting information and knowledge through experience about technology. This result agrees well with other studies such as those by Kebede et al. [37], Ketema and Kebede [38], Abera [39], and Asfaw et al. [40]. Similarly, Hagos [41] found a positive influence of age on agricultural technology adoption. Conversely, Hailu et al. $[42,43]$ found a negative influence of age on the adoption of technology confirming that the younger age groups are adopters compared to their counterparts, the elders. The age of the head of the household can be used to capture the farming experience. Studies in Ethiopia by Kebede et al. [44] have also shown a positive relationship between the number of years of experience in agriculture and the adoption of improved agricultural technologies, while a study in [45] indicates a negative relationship between age and adoption of improved soil conservation practices. Older age is believed to be associated with access to information on improved technologies and higher productivity through experience. Therefore, farmers with older ages are more likely better to adopt coffee shade agroforestry technology.

Education was found to have positive relationships with planting coffee shade trees. This result showed that higher educational status increases the awareness of farmers about the values and benefits of the shade tree (Table 5). In the same way, the result agreed with the findings of [46] on the adoption of other technologies such as fertilizer application and [47] also observed that education of the household head positively influenced the chances of adopting improved varieties of barley and wheat. The odds ratio result shows that the education level increases the decision of the farmers to adopt coffee shade agroforestry technology by 5.01 factors (Table 5).

A higher level of education is believed to be associated with access to information on improved technologies and higher productivity [48]. Therefore, farmers with higher 
TABLE 3: Description of the variables affecting the adoption of the technology.

\begin{tabular}{|c|c|c|c|}
\hline Variables in the model & $\begin{array}{l}\text { Types of } \\
\text { variables }\end{array}$ & Description of the variable & $\begin{array}{l}\text { Expected } \\
\text { sign }\end{array}$ \\
\hline Sex & Dummy & 1 if male, 0 otherwise & $+1-$ \\
\hline Age & Categorical & $\begin{array}{c}\text { Category } 1=\text { age in } 20-30 \text { yrs, category } 2=\text { age in } 30-40 \text { yrs, category } 3=\text { age in } \\
40-50 \mathrm{yrs} \text {, and category } 4=\text { age above } 50 \mathrm{yrs}\end{array}$ & + \\
\hline Education level $=$ Educ & Categorical & $1=$ none, $2=$ primary, $3=$ secondary, and $4=$ above & + \\
\hline $\begin{array}{l}\text { HHcomp }=\mathrm{HH} \\
\text { composition }\end{array}$ & Categorical & $\begin{array}{c}\text { Category } 1=\text { member }<4 \text {, category } 2=\text { member } 5-8 \text {, category } 3=\text { member } \\
9-12 \text {, and category } 4=\text { member above } 12\end{array}$ & $+1-$ \\
\hline $\begin{array}{l}\text { Farmsiz/total farm size } \\
\text { (ha) }\end{array}$ & Categorical & Farmsz $1,<2$; farmsz 2, 2-3.5; farmsz 3, 3.5-5; and farmsz 4, less than 5 & + \\
\hline $\begin{array}{l}\text { Areacoff }=\text { total area of } \\
\text { coffee (ha) }\end{array}$ & Categorical & $\begin{array}{l}\text { Areacoff } 1=0-0.11, \text { areacoff } 2=0.11-0.125 \text {, areacoff } 3=0.125-0.25 \text {, and } \\
\text { areacoff } 4=0.25-1\end{array}$ & $+/-$ \\
\hline Training & Dummy & 1 if get training, 0 otherwise & + \\
\hline Extension & Dummy & 1 if access to service, 0 otherwise & + \\
\hline
\end{tabular}

TABLE 4: Basic HH characteristics in the study area.

\begin{tabular}{|c|c|c|c|}
\hline & Category & Frequency & Percent \\
\hline \multirow{5}{*}{ Age } & $20-30$ & 21 & 17.5 \\
\hline & $30-40$ & 40 & 33.3 \\
\hline & $40-50$ & 41 & 34.2 \\
\hline & Above 50 & 18 & 15 \\
\hline & Total & 120 & 100 \\
\hline \multirow{3}{*}{ Sex } & Male & 96 & 80 \\
\hline & Female & 24 & 20 \\
\hline & Total & 120 & 100 \\
\hline \multirow{4}{*}{ Marital status } & Married & 116 & 96.7 \\
\hline & Single & 3 & 2.5 \\
\hline & Divorced & 1 & 0.8 \\
\hline & Total & 120 & 100 \\
\hline \multirow{4}{*}{ HH composition } & Less than 4 & 47 & 39.2 \\
\hline & 5-8 & 69 & 57.5 \\
\hline & $9-12$ & 4 & 3.3 \\
\hline & Total & 120 & 100 \\
\hline \multirow{5}{*}{ Education level } & None & 29 & 24.2 \\
\hline & Primary & 75 & 62.5 \\
\hline & Secondary & 13 & 10.8 \\
\hline & Above & 3 & 2.5 \\
\hline & Total & 120 & 100 \\
\hline \multirow{5}{*}{ Total farm size (ha) } & $<2$ & 44 & 36.7 \\
\hline & $2-3.5$ & 57 & 47.5 \\
\hline & $3.5-5$ & 16 & 13.3 \\
\hline & $>5$ & 3 & 2.5 \\
\hline & Total & 120 & 100 \\
\hline \multirow{5}{*}{ The total area covered by coffee (ha) } & $0-0.11$ & 20 & 16.7 \\
\hline & $0.11-0.125$ & 27 & 22.5 \\
\hline & $0.125-0.25$ & 37 & 30.8 \\
\hline & $0.25-1$ & 36 & 30 \\
\hline & Total & 120 & 100 \\
\hline
\end{tabular}

levels of education are more likely better to adopt coffee shade agroforestry technology.

The output of the model for farm size shows that farm size is among the major positive determinants of coffee shade agroforestry technology adoption and it is statistically not significant (Table 5). As a result, the addition of one more hectare of the land to coffee production increases the chance of planting a shade tree by a factor of 14.06; other factors remained constant. The regression result showed that as the size of land owned by an individual increases, the probability of an individual plant shade tree would increase (Table 5). Kebede et al. [37], Ahmed [46], Shiferaw et al. [49], and Liechty et al. [50] have observed similar positive influence of farm size on the adoption of new technologies. In a different line to this finding, Amponsah et al. [38, 51] observed the negative influence of farm size with the adoption of crop technologies. Farm size is also considered as a factor that influences the adoption decisions of farmers. 
TABLE 5: Logistic regression results of variables affecting coffee shade tree planting.

\begin{tabular}{lccccc}
\hline Adoption & $\beta$ & Std. err. & $Z$ & $P>|z|$ & $\operatorname{Exp}(\beta)$ \\
\hline Sex & -0.74 & 1.35 & -0.55 & 0.58 & $0.48^{\text {ns }}$ \\
Age & 3.39 & 1.19 & 2.86 & 0.00 & $29.75^{* * *}$ \\
Educ & 1.61 & 0.91 & 1.77 & 0.08 & $5.01^{\text {ns }}$ \\
HHcomp & 2.78 & 1.32 & 2.11 & 0.04 & $16.06^{* *}$ \\
Farmsiz & 2.64 & 1.44 & 1.84 & 0.07 & $14.06^{\text {ns }}$ \\
Areacoff & 2.15 & 0.84 & 2.57 & 0.01 & $8.58^{* * *}$ \\
Training & 4.27 & 2.07 & 2.06 & 0.04 & $71.33^{* *}$ \\
Extension & 2.08 & 1.24 & 1.68 & 0.09 & $7.98^{\text {ns }}$ \\
Constant & -22.47 & 7.13 & -3.15 & 0.00 & $0.00^{* * *}$ \\
\hline
\end{tabular}

Number of obs $=120$, LR $_{\text {chi }}{ }^{2}(8)=121.71$, prob $>$ chi $^{2}=0.0000$, pseudo$R^{2}=0.8042$, and $\log$ likelihood $=-14.814462 .{ }^{* * *}$ represents that adoption of the technology is significantly affected by $\leq 1 \%,{ }^{* *}$ is significantly affected by $5 \%$, and ns means not significant; $\beta$ is a vector of parameters to be estimated.

The relationship between farm size and technology adoption varies from country to country [52].

$\mathrm{HH}$ composition, the member of the family, positively and significantly influenced the adoption of coffee shade agroforestry technology at a $5 \%$ level of significance (Table 5). So this result shows that as a member of the $\mathrm{HH}$ increases, the adoption probability of this technology increases by the factor of 16.06; other factors remain constant. This result is in line with the findings of Kebede et al., [37] where as the family members increased, the adoption of new technology increased. Nevertheless, Ketema and Kebede [38] observed that negative relationship as family size increases the level of adoption of technology decline in the case of fertilizer applicationa. The influence of $\mathrm{HH}$ composition on coffee shade agroforestry technology can be seen from two angles. The first assumption is that $\mathrm{HH}$ with large families may be forced to divert part of the labor force to offfarm activities in an attempt to earn income to ease the consumption pressure imposed by a large family [53]. The other assumption is that large family size is normally associated with a higher labor endowment, which would enable an $\mathrm{HH}$ to accomplish various agricultural tasks. Croppenstedt et al. [54] argue that households with a larger team of labor are more likely to adopt agricultural technology and use it more intensively because they have fewer labor shortages at peak times.

The area of land allocated to coffee production influenced the decision to plant shade trees on their coffee farm. Coffee production in the study area was a garden coffee production system and the farmers did not allocate a large area. The coefficient of the result implies that the area allocated for coffee production increases the decision of planting coffee shade by 8.58 factors, with other factors remaining constant. That means the area allocated for coffee has a positive relation with shade tree planting at a $1 \%$ level of significance (Table 5). This finding is in line with the findings in Ethiopia by Tura et al. [55], reported that as the portion of land allocated for maize production increases, the use of improving maize variety also increases.

Extension contact of the farmer influenced the adoption of the coffee shade tree positively but the result is not significant (Table 5). The result of the odds ratio shows that contact of extension can raise the chance of planting coffee shade trees by the factor of 7.98 , with other factors remaining constant. Access to the extension has been extensively taken into account to positively influence the adoption and continued use of agricultural technologies [56]. Yirga et al. [47] reported that extension contacts do not have significant effects on the adoption of the improved varieties of crops, suggesting that mere provision of information would add little to changing the mindset of farmers.

Access to training significantly influenced planting coffee shade trees at a $5 \%$ level. The chances of planting coffee shade tree agroforestry technology increases as the farmer gets training. The odds ratio value of the model shows that training can increase the chance of adopting technology by 71.33 factors; other factors remained constant (Table 5). This finding agreed with [47]: access to training on improved varieties of crops significantly and positively influenced the chances of adopting improved varieties of barley, potatoes, and fava beans. But Liechty et al. [50] observed that training does not significantly influence the adoption of agroforestrybased land management practice; rather, it facilitates the process.

3.2.1. Training and Extension Services. The majority of the respondents (87.5\%) in the area had attended some training on coffee-based agroforestry practices, while the rest (12.5\%) had not (Table 2). This means that many respondents were able to make informed choices on what they do on their farms. Those who had attended training reported having had already gained some knowledge and acquired some skills which had helped them to the made decision of adoption. This implies that regular extension contact and training for farmers are necessary because they motivate, expose, and cultivate interest and create a positive attitude towards the adoption of technology. They also had helped them to gain knowledge and information on the benefits and uses of new technology.

Extension services and different pieces of training on coffee production correspond to access to the information required to decide whether to adopt coffee shade agroforestry technology. Various studies in developing countries including Ethiopia report a strong positive relationship between access to information and the adoption behavior of farmers [53]. Frequently, the uptake of new technology is said to be subjective to the farmer's contact with extension services. Reasonable access to extension services would significantly increase adoption technology [57]. However, fine or poorly performed extension education can also be a major factor in influencing the toughness and adoption of new technology [58].

3.2.2. Total Landholding and the Total Area Covered by Coffee. The result shows that the total area covered by coffee is affected by the total landholding of the HHs (Table 6). In Ethiopia, holding size is among the most crucial assets that determine the adoption status of farmers. For example, a study by [59], on the adoption of improved wheat varieties in 
TABLE 6: The relationship of total landholding of the HHs and the area covered by coffee (\%).

\begin{tabular}{lccccc}
\hline $\begin{array}{l}\text { Total farm size } \\
\text { (ha) }\end{array}$ & \multicolumn{5}{c}{ The area covered by coffee (ha) } \\
\hline$<2$ & $0-0.11$ & $0.11-0.125$ & $0.125-0.25$ & $0.25-1$ & Total \\
\hline-3.5 & 15 & 11.7 & 5.8 & 4.2 & 36.7 \\
$3.5-5$ & 0 & 10 & 20 & 17.5 & 52.5 \\
$>5$ & 1.7 & 0.8 & 5 & 5.8 & 13.3 \\
Total & 0 & 0 & 0 & 2.5 & 2.5 \\
\hline
\end{tabular}

Northwestern Ethiopia, indicates that landholding size can affect the rate of adoption.

3.3. Why Farmers Did Not Plant Shade Trees? The respondents who were not planting shade trees mentioned their reasons. The reasons were lack of awareness on the values and benefits of shade tree planting, the negative response of coffee production under irrigation, and lack of large farm size (Table 7).

3.4. Preference of Farmers on Coffee Shade Trees. From the total respondents, $67.5 \%$ were adopters of shade trees and $32.5 \%$ were not adopters of shade trees (Figure 2). Planted shade trees in the area were mentioned as Sesbania sesban, Cordia africana, Albizia gummifera, and Acacia abyssinica and the least were Leucaena leucocephala preferred in consequence (Figure 2).

Shade tree selection is a difficult experience, especially for diverse, multistratum, and low-input plantations where farmers' understanding and the forces of secondary succession interact [60]. Another study confirmed that the coffee shade tree species selection is based on farmers' knowledge of the morphological, physiological (the nature of its canopy cover), and ecological features of indigenous tree species [60]. Considering these parameters, the trees identified as suitable for coffee plantations are Albizia sp., Ficus sp., Acacia albida, Cordia africana, Leucaena leucocephala, Citrus sinensis, Sesbania sesban, Grevilia robusta, Pterocarpus marsupium, Cedrella toona, Artocarpus integrifolia, Artocarpus hirsute, Bischofia javanica, Erythrina lithosperma, Terminalia bellirica, and so forth. It is desirable to have a mixture of all these trees in a given plantation for providing top canopy shade [61].

The preference of coffee shade trees showed that farmers' decision on tree management in their plantation based on tree characteristics such as height, crown width, leaf size, and deciduousness and litter decomposition rate [62], leaf and crown characteristics, tree height, and their impact on coffee yield [63]. The study of [64] shows that management could strongly influence the main drivers of coffee growth and yield: photosynthesis, shade temperature, or light use efficiency. Increasing the efficiency of shade management buffering with increasing temperatures could encourage stakeholders to grow coffee plantations under high coverage shade trees without pruning because; even low densities can reduce maximum daily canopy temperature without the
TABLE 7: Nonadopters' reasons not to plant shade trees $(n=39)$.

\begin{tabular}{lc}
\hline Why do you not plant coffee shade? & Percent \\
\hline No awareness & 10.8 \\
It is not suitable for irrigation & 5 \\
I do not have free spaces & 15 \\
I have enough shade trees & 1.7 \\
Total & 32.5 \\
\hline
\end{tabular}

expense of high tree densities or intensive pruning of shade trees such as Cordia alliodora [64].

3.5. Other Benefits of Coffee Shade Trees. The majority of the interviewed farmers perceived other desirable benefits derived from shade trees. Some of the mentioned benefits of shade trees are fodder, firewood, timber value, construction materials, erosion control, improved soil fertility, honey bee production, and medicinal value. All shade trees are grown in coffee plantation because of the additional economic benefits that they provide to the farmers. As the respondents of the study area replied, these benefits of shade trees are ranked as in Table 8 .

According to the respondents, Sesbania sesban was typically superior by fodder and firewood contribution: $30.8 \%$ and $26.7 \%$ of the respondents, respectively, report it. Albizia gummifera was superior by soil erosion control that $17.5 \%$ of the respondents were responding it and it was the only shade tree mentioned for the medicinal purpose (6.7\%) in the area. Cordia africana was considered superior for construction materials (35\%) and it was the only shade tree mentioned for timber production $(15.8 \%)$ by the respondents in the area (Table 8).

Franzel and Shurr [65] assumed that planting tree species that produce high-value fruits, fodder, and timber is driven commercially, as they are deliberately planted and more intensively managed as an investment. Biggelaar and Gold [66] believed that native tree species naturally regenerated in agroforestry practices are managed less intensively but still serve multiple utilities, not only for direct consumption such as fuel and construction materials but also for ecosystem services such as shade and as windbreaks, soil fertility enhancement, and soil erosion control.

Farmers sustain trees in their coffee farms for additional functions such as fruit trees, firewood, or honey production $[60,63]$. Under careful management systems, shade trees provide substantial revenue to the coffee growers in the form of timber, firewood, edible fruits, and so forth [61].

Protector makes a diverse layer of shade trees, combining natural shade trees for enhanced functional biodiversity, erosion control, carbon sequestration, soil fertility, drought resistance, and serve as a shade, with particularly useful multipurpose species such as legume trees for nitrogen fixation and wood production [67]. Shade trees provided environmental values by their forest-like structure [68]. They also have social and economic value in reducing the vulnerability of households to climatic stress, pest outbreaks, falling prices, and food insecurity. Growing coffee under shade trees allows other sources of income. These are 


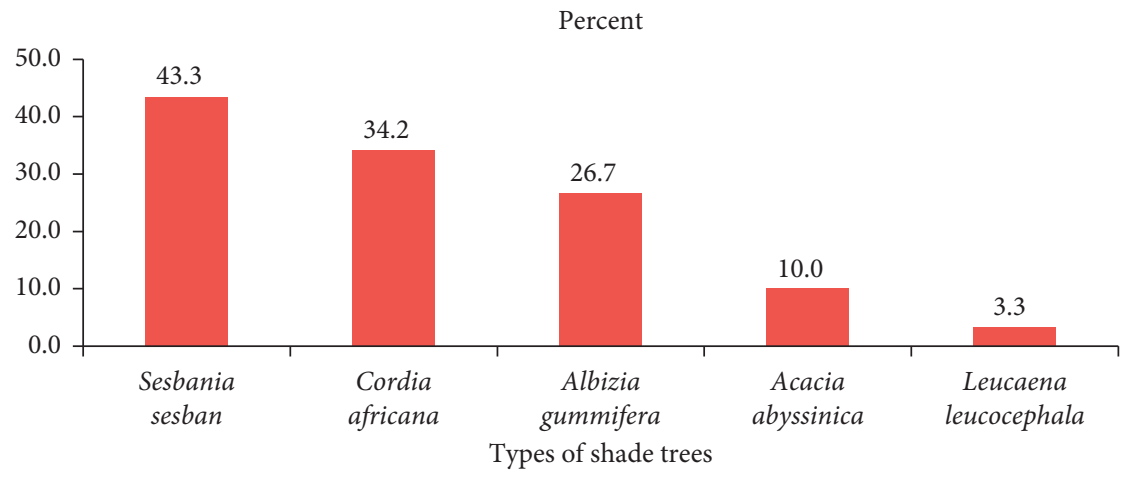

Percent

FIgURE 2: Types of shade trees planted by adopters in the area.

TABLE 8: Uses of shade trees planted by adopters in addition to shading value in Gobu Seyo district.

\begin{tabular}{|c|c|c|c|c|c|c|}
\hline \multirow{2}{*}{ Uses of shade trees } & \multicolumn{5}{|c|}{ No. of HHs and types of shade trees planted by adopters } & \multirow{2}{*}{$\%$} \\
\hline & Sesbania sesban & Leucaena leucocephala & Albizia gummifera & Cordia africana & Acacia abyssinica & \\
\hline Fodder & 37 & 3 & - & - & 2 & 35 \\
\hline Firewood & 32 & 1 & 8 & - & 12 & 44.2 \\
\hline Improve soil fertility & 15 & - & - & - & - & 12.7 \\
\hline Fence & 10 & 1 & 5 & - & 4 & 16.7 \\
\hline For erosion control & - & - & 21 & - & - & 17.5 \\
\hline Medicinal purpose & - & - & 8 & - & - & 6.7 \\
\hline Construction materials & - & - & 9 & 42 & - & 42.5 \\
\hline Honey bee production & - & - & - & 25 & 8 & 27.5 \\
\hline Timber production & - & - & - & 19 & - & 15.8 \\
\hline Total & 94 & 5 & 51 & 88 & 26 & - \\
\hline
\end{tabular}

fruits, fuelwood, and timber; it could be also socially more acceptable, economically more viable, and environmentally more sustainable [69].

The shade trees in coffee production systems provide numerous economic and ecological benefits. Several studies have demonstrated the multiple uses of coffee shade trees and their role in soil fertility management [70, 71]. Shade trees are used for biodiversity conservation [72, 73]. For carbon sequestration [74], microclimate regulation and prevention of coffee plants from damage by frost or other extreme conditions [75] and cash income generation from the sale of timber and nontimber products [76] have been well documented.

3.6. Shade Management Practices. Farmers manage the shade tree canopy to optimize coffee production while maximizing the use of the different tree species. Concerning management practice, the responses of the farmers in the study area were identified (Table 9). Shade management options are available to improve the attractiveness of coffee systems, while simultaneously maintaining coffee output at regular and productive levels. Dead or dry weeds and the residues of pruning can be used as mulch. Mulching will reduce the number of weeds, as well as water losses by evaporation, and add soil microorganism by the decomposition process.
TABLE 9: Shade tree management practices experienced by adopters in Gobu Seyo Woreda $(n=81)$.

\begin{tabular}{lc}
\hline Managements & Frequency \\
\hline Pruning & 22 \\
Mulching & 10 \\
Pruning and mulching & 26 \\
Pruning, watering, and composting & 8 \\
Mulching, watering, and composting & 15 \\
\hline
\end{tabular}

The traditional coffee management practice includes thinning of the tree canopy by purposively maintaining certain tree species in the semiforest and semiplantation coffee systems [77-79].

3.7. Socioeconomic and Environmental Benefits of Shade Trees. This section deals with the socioeconomic and environmental benefits of adopting coffee shade tree agroforestry. Most of the information on this adoption was obtained through interviews. Table 10 reveals that $67.5 \%$ of the respondents reported socioeconomic and environmental benefits of shade trees by practicing coffee shade tree agroforestry technology planting.

Among other ecological benefits, shade trees are believed to provide substantial economic benefit to coffee growers in the form of wood, firewood, edible fruits, and so forth. This 
TABLE 10: Socioeconomic and environmental importance of shade trees mentioned by farmers in Gobu Seyo Woreda.

\begin{tabular}{lcc}
\hline \multirow{2}{*}{ Socioeconomic benefit } & \multicolumn{2}{c}{ No. of HHs } \\
& Frequency & $\%$ \\
\hline House tools & 28 & 23.3 \\
Honey bee production & 38 & 31.7 \\
Source of feed for animal and human & 19 & 15.8 \\
Construction materials & 9 & 7.5 \\
Source of energy/charcoal and firewood & 36 & 30.0 \\
Source of medicine & 8 & 6.7 \\
\hline Environmental benefit & & \\
Improve soil fertility & 68 & 56.7 \\
Erosion control & 79 & 65.8 \\
Serve as windbreak & 31 & 25.8 \\
Minimize environmental pollution & 70 & 58.3 \\
\hline
\end{tabular}

is, therefore, a worthy compromise among an acceptable decline in coffee plant productivity and diversification of revenues from sales of timber products and fruit [4].

Shade trees reduce evaporative demand and, hence, drought stress of understory plants. Improved growing conditions and reduced drought stress in shaded conditions are observed in the coffee shade agroforestry system [68].

Leguminous shade trees have been shown to improve soil quality by the fixation of nitrogen. Pruning of leguminous species shade trees and using the cuttings as mulch improve the soil nitrogen content and minimize the croptree competition for light and water. The shade tree canopy can control the temperatures and the humidity levels and keep the soil water from evaporating by a cover of leaf litter [80]. A tree with a pruned crown will transpire less and thereby use less water [81].

The system is also an ideal way for the leaf and other falls of the tree shade will add to the organic matter content of the soil by contributing organic biomass to the litter [4]. Various researches discovered that trees contribute biomass (leaf litter, small twigs), which is among the essential elements of maintaining the organic matter content in the soil [4]. Various nutrients in the deep strata of soil will also be absorbed by the deep root system of shade trees and will be availed to the upper layers of the soil in the form of biomass [4].

The inclusion of legume trees can improve the nutrient status of the soil [82]. This is because of symbiosis with the Rhizobium bacteria that provide the plant with nitrogen taken from the atmosphere $[83,84]$. Trees have been shown to improve soil fertility through better nutrient cycling, since their roots go deep down in the soil and reach nutrients that may not be accessible to the coffee plants [85].

Shade trees help to minimize the erosive power of rainfall by acting as a physical barrier in reducing the intensity of the rain reaching the ground. They also help in the deep infiltration of rainwater because of their deep rooting system; this in turn will contribute to the recharging of groundwater [4]. Shaded plantations are also well protected against drought effects. The cool temperature above the coffee bushes, due to shade, ensures that the loss of soil moisture through evaporation and transpiration is minimized. Moreover, the shaded plantations being rich in soil organic matter retain moisture for longer periods during dry months when compared to open conditions [4].

\section{Conclusion and Recommendation}

4.1. Conclusion. The adoption of coffee shade agroforestry technology has to pay a considerable awareness of researchers and policymakers. While farmers adopt new technology, several factors can influence their decision to choose technology. This study has been dedicated to analyzing the factors influencing the adoption of agroforestry technologies. An agroforestry technology may considerably increase yields or agricultural productivity when it has been adopted. It also solves the problem of livelihood and adds economic and environmental benefits. It also supplies many benefits to the farmers including the source of income, for different house tools, source of foods, source of fuel/firewood and charcoal, for construction materials, source of fodder, for medicinal purpose, for erosion control, and soil fertility enhancement. However, the introductions of the technology have met with only partial success, as measured in observed rates of adoption.

Coffee shade agroforestry technology was important to diversify the agricultural products and to solve the problems related to deforestation by increasing the land cover system. Particularly, it is the land use system that was recommended in the area, to minimize high temperature that negatively affects the coffee production system.

4.2. Recommendation. Based on the findings of this study, the following statements were recommended:

(i) Since this agroforestry technology has the potential to provide economic, social, and environmental benefits that are capable of solving the problem of household income, livelihoods and food insecurity, and environment-related challenges, different pieces of training should be prepared and given to the farmers to develop their awareness on the technology.

(ii) To guarantee endorsement of the extension of coffee shade agroforestry technology, the rural households must participate in pieces of training to improve their productivity and maximize the benefits of coffee shade agroforestry technology.

(iii) Further research is needed for detailed assessments of shade tree management activities basically on coffee productions under irrigation systems.

\section{Data Availability}

The data used to support the findings of this study are available from the corresponding author upon request.

\section{Conflicts of Interest}

The authors declare that they have no conflicts of interest. 


\section{References}

[1] J. R. Alavalapati, D. E. Mercer, and J. R. Montambault, "Agroforestry systems and valuation methodologies," in Valuing Agroforestry Systems, pp. 1-8, Springer, Dordrecht, Netherlands, 2004.

[2] L. Ehrenbergerová, M. Šenfeldr, and H. Habrová, "Impact of tree shading on the microclimate of a coffee plantation: a case study from the Peruvian Amazon," Bois \& Forets Des Tropiques, vol. 334, pp. 13-22, 2017.

[3] J. Recha, M. Kapukha, A. Wekesa, S. Shames, and K. Heiner, Sustainable Agriculture Land Management Practices for Climate Change Mitigation: A Training Guide for Smallholder Farmers, 2014.

[4] M. M. Alemu, "Effect of tree shade on coffee crop production," Journal of Sustainable Development, vol. 8, no. 9, p. 66, 2015.

[5] B. B. Lin, I. Perfecto, and J. Vandermeer, "Synergies between agricultural intensification and climate change could create surprising vulnerabilities for crops," BioScience, vol. 58, no. 9, pp. 847-854, 2008.

[6] R. G. Muschler, "Shade improves coffee quality in a suboptimal coffee-zone of Costa Rica," Agroforestry Systems, vol. 51, no. 2, pp. 131-139, 2001.

[7] J. Vandermeer, I. Perfecto, and S. Philpott, "Ecological complexity and pest control in organic coffee production: uncovering an autonomous ecosystem service," BioScience, vol. 60, no. 7, pp. 527-537, 2010.

[8] L. Pumariño, G. W. Sileshi, S. Gripenberg et al., "Effects of agroforestry on pest, disease and weed control: a metaanalysis," Basic and Applied Ecology, vol. 16, no. 7, pp. 573-582, 2015.

[9] J. Dahlqvist, What is the View of the Black Coffee Twig Borer (Xylosandrus Compactus (Eichhoff)) among Farmers, Advisers and Experts, and is the Infestation on Robusta Coffee Trees (Coffea Canephora) Higher or Lower When Grown Close to a Ficus Natalensis?, Swedish University of Agricultural Sciences, Uppsala, Sweden, 2016.

[10] P. H. Thangata and J. R. R. Alavalapati, "Agroforestry adoption in southern Malawi: the case of mixed intercropping of Gliricidia sepium and maize," Agricultural Systems, vol. 78, no. 1, pp. 57-71, 2003.

[11] A. A. Adesina, D. J. Sonwa, S. F. Weise et al., "The role of cocoa agroforests in rural and community forestry in Southern Cameroon," in Rural Development Forestry Network Paper $25 g, 2001$.

[12] C. R. Doss and M. L. Morris, "How does gender affect the adoption of agricultural innovations? The case of improved maize technology in Ghana," Agricultural Economics: The Journal of the International Association of Agricultural Economists, vol. 25, pp. 27-39, 2001.

[13] A. Gebrelibanos, "Farmers' perception and adoption of integrated striga management technology," M. S thesis, Haramaya University, Haramaya, Ethiopia, 2006.

[14] T. Mume, "Determinants of intensity of adoption of improved onion production package in dugda bora district, East Showa, Ethiopia," Haramaya University of Agriculture, Dire Dawa, Ethiopia, M. sc theses, 2007.

[15] Y. Birhe, "The legal regime regulating coffee trade in Ethiopia," MSc Thesis, Addis Ababa University, Faculty of Law, School of Graduate Studies, Ababa, Ethiopia, 2010.

[16] M. Fridell, I. Hudson, and M. Hudson, "With friends like these: the corporate response to fair trade coffee," Review of Radical Political Economics, vol. 40, no. 1, pp. 8-34, 2008.
[17] J. Finley-Lezcano, D. King, and T. Wang, Adaptation to Climate Change by Smallholder Coffee Producers in Latin America, USAID, Washington, DC, USA, 2016.

[18] FAO, World Reference Base for Soil Resources 2006: A Framework for International Classification, Correlation and Communication, World Soil Resources Reports, FAO, Rome, Italy, 2006.

[19] J. G. B. Leenaars, E. Eyasu, H. Wösten et al., Major SoilLandscape Resources of the Cascape Intervention Woredas, Ethiopia, 2016.

[20] C. R. Kothari, "Research methodology: methods and techniques," New Age International, 2004.

[21] S. A. Kim, J. M. Gillespie, and K. P. Paudel, "Count data analysis of the adoption of best management practices in beef cattle production," in Proceedings of the Southern Agricultural Economics Association Annual Meetings, Little Rock, AR, USA, February 2005.

[22] T. Isgin, A. Bilgic, D. L. Forster, and M. T. Batte, "Using count data models to determine the factors affecting farmers' quantity decisions of precision farming technology adoption," Computers and Electronics in Agriculture, vol. 62, no. 2, pp. 231-242, 2008.

[23] A. Sharma, A. Bailey, and I. Fraser, "Technology adoption and pest control strategies among UK cereal farmers: evidence from parametric and nonparametric count data models," Journal of Agricultural Economics, vol. 62, no. 1, pp. 73-92, 2011.

[24] M. Burton, D. Rigby, and T. Young, "Analysis of the determinants of adoption of organic horticultural techniques in the UK," Journal of Agricultural Economics, vol. 50, no. 1, pp. 47-63, 1999.

[25] P. Zhou, "Lands cape-scale soil erosion modeling and ecological restoration for a mountainous watershed in Sichuan, China," Tropical Forestry Reports, University of Helsinki, Helsinki, Finland, 2008.

[26] G. Feder, R. E. Just, and D. Zilberman, "Adoption of agricultural innovations in developing countries: a survey," Economic Development and Cultural Change, vol. 33, pp. 255-299, 1985.

[27] D. W. Hosmer, S. Lemeshow, and J. Klar, "Goodness-of-fit testing for the logistic regression model when the estimated probabilities are small," Biometrical Journal, vol. 30, no. 8, pp. 911-924, 1988.

[28] D. W. Hosmer, S. Lemeshow, and S. Lemeshow, Applied Logistic Regression: Wiley Series in Probability and Statistics: Texts and References Section, Wiley, Hoboken, NJ, USA, 2000.

[29] J. F. Hair, W. C. Black, B. J. Babin, R. E. Anderson, and R. L. Tatham, Multivariate Data Analysis, Pearson Prentice Hall Upper, Saddle River, NJ, USA, 6th edition, 2006.

[30] N. L. Leech and A. J. Onwuegbuzie, "Qualitative data analysis: a compendium of techniques and a framework for selection for school psychology research and beyond," School Psychology Quarterly, vol. 23, no. 4, p. 587, 2008.

[31] J. F. Pallant and A. Tennant, "An introduction to the Rasch measurement model: an example using the Hospital Anxiety and Depression Scale (HADS)," British Journal of Clinical Psychology, vol. 46, no. 1, pp. 1-18, 2007.

[32] S. Sweet and K. G. Martin, Data Analysis with SPSS: A First Course in Applied Statistics, Pearson Education, Inc., Publishing as Allyn\& Bacon, Boston, MA, USA, 4th edition, 2012.

[33] A. Agresti, B. Finlay, and M. Porcu, Statistica Per le Scienze Sociali, Pearson, London, UK, 2009.

[34] B. G. Tabachnick and L. S. Fidell, Experimental Designs Using ANOVA, Thomson/Brooks/Cole, Belmont, CA, USA, 2007. 
[35] J. F. Hair, R. E. Anderson, R. L. Tatham, and W. C. Black, Multivariate Data Analysis with Readings, Pearson, London, UK, 4th edition, 1995.

[36] R. Field, B. A. Hawkins, H. V. Cornell et al., "Spatial speciesrichness gradients across scales: a meta-analysis," Journal of Biogeography, vol. 36, no. 1, pp. 132-147, 2009.

[37] D. Kebede, M. Ketema, N. Dechassa, and F. Hundessa, "Determinants of adoption of wheat production technology package by smallholder farmers: evidences from eastern Ethiopia," Turkish Journal of Agriculture-Food Science and Technology, vol. 5, pp. 267-274, 2017.

[38] M. Ketema and D. Kebede, "Adoption intensity of inorganic fertilizers in maize production: empirical evidence from smallholder farmers in Eastern Ethiopia," Journal of Agricultural Science, vol. 9, no. 5, p. 124, 2017.

[39] H. B. Abera, "Adoption of improved tef and wheat production technologies in crop-livestock mixed systems in northern and western shewa zones of ethiopia," Ph. d thesis, University of Pretoria, Pretoria, South Africa, 2008.

[40] S. Asfaw, M. Kassie, F. Simtowe, and L. Lipper, "Poverty reduction effects of agricultural technology adoption: a microevidence from rural Tanzania," Journal of Development Studies, vol. 48, no. 9, pp. 1288-1305, 2012.

[41] B. G. Hagos, "Impact of agricultural technology adoption of smallholder farmers on wheat yield: empirical evidence from the Southern Tigrai State of Ethiopia," Journal of Agricultural Extension and Rural Development, vol. 8, no. 10, pp. 211-223, 2016.

[42] B. K. Hailu, B. K. Abrha, and K. A. Weldegiorgis, “Adoption and impact of agricultural technologies on farm income: evidence from Southern Tigray, Northern Ethiopia," IJFAEC, vol. 2, no. 4, pp. 91-106, 2014.

[43] M. Jaleta, M. Kassie, and P. Marenya, "Impact of improved maize variety adoption on household food security in Ethiopia: an endogenous switching regression approach," in Proceedings of the International Conference of Agricultural Economists, Milan, Italy, May 2015.

[44] Y. Kebede, K. Kunjal, and G. Coffin, "Adoption of new technologies in Ethiopian agriculture: the case of TeguletBulga district Shoa province," Agricultural Economics, vol. 4, no. 1, pp. 27-43, 1990.

[45] B. Shiferaw and S. T. Holden, "Resource degradation and adoption of land conservation technologies in the Ethiopian highlands: a case study in Andit Tid, North Shewa," Agricultural Economics, vol. 18, no. 3, pp. 233-247, 1998.

[46] M. H. Ahmed, "Adoption of multiple agricultural technologies in maize production of the Central Rift Valley of Ethiopia," Studies in Agricultural Economics, vol. 117, no. 3, pp. 162-168, 2015.

[47] C. Yirga, Y. Atnafe, and A. AwHassan, "A multivariate analysis of factors affecting the adoption of improved varieties of multiple crops: a case study from Ethiopian highlands," Ethiopian Journal of Agricultural Sciences, vol. 25, pp. 29-45, 2015.

[48] P. E. Norris and S. S. Batie, "Virginia farmers' soil conservation decisions: an application of Tobit analysis," Journal of Agricultural and Applied Economics, vol. 19, no. 1, pp. 79-90, 1987.

[49] B. Shiferaw, M. Kassie, M. Jaleta, and C. Yirga, "Adoption of improved wheat varieties and impacts on household food security in Ethiopia," Food Policy, vol. 44, pp. 272-284, 2014.

[50] H. O. Liechty, M. Blazier, M. Pelkki, D. White Jr., and Z. Robinson, "The potential for using agroforests for bioenergy production in the Lower Mississippi Alluvial Valley," in Proceedings of the Small-Scale Forestry Conference 2012: Science for Solutions Conference Proceedings, pp. 88-92, Family Forest Research Center, Amherst, MA, USA, September 2012.

[51] E. K. Amponsah, E. Aboagye, and O. S. Agyemang, "Crop technology adoption among rural farmers in some selected regions of Mali," Journal of Sustainable Development, vol. 6, no. 10 , p. $25,2013$.

[52] C. Gardebroek, "Farm-specific factors affecting the choice between conventional and organic dairy farming," Zaragoza (Spain), vol. 28, p. 31, 2002.

[53] C. Y. Tizale, "The dynamics of soil degradation and incentives for optimal management in the central highlands of Ethiopia," Ph. D thesis, University of Pretoria, Pretoria, South Africa, 2007.

[54] A. Croppenstedt, M. Demeke, and M. M. Meschi, "Technology adoption in the presence of constraints: the case of fertilizer demand in Ethiopia," Review of Development Economics, vol. 7, no. 1, pp. 58-70, 2003.

[55] M. Tura, D. Aredo, W. Tsegaye et al., "Adoption and continued use of improved maize seeds: a case study of Central Ethiopia," African Journal of Agricultural Research, vol. 5, pp. 2350-2358, 2010.

[56] D. Knowler and B. Bradshaw, "Farmers' adoption of conservation agriculture: a review and synthesis of recent research," Food Policy, vol. 32, no. 1, pp. 25-48, 2007.

[57] S. W. Ndiritu, M. Kassie, and B. Shiferaw, "Are there systematic gender differences in the adoption of sustainable agricultural intensification practices? Evidence from Kenya," Food Policy, vol. 49, pp. 117-127, 2014.

[58] M. Abbas, T. E. Lodhi, K. M. Aujla, and S. Saadullah, "Agricultural extension programs in Punjab, Pakistan," Pakistan Journal of Life and Social Sciences, vol. 7, no. 1, pp. 1-10, 2009.

[59] T. Zegeye, G. Taye, D. G. Tanner, H. Verkuijl, A. Agidie, and W. M. Mwangi, Adoption of Improved Bread Wheat Varieties and Inorganic Fertilizer by Small-Scale Farmers in Yelmana Densa and Far Districts of Northwestern Ethiopia, CIMMYT, Mexico City, Mexico, 2001.

[60] L. Soto-Pinto, V. Villalvazo-López, G. Jiménez-Ferrer, N. Ramírez-Marcial, G. Montoya, and F. L. Sinclair, "The role of local knowledge in determining shade composition of multistrata coffee systems in Chiapas, Mexico," Biodiversity and Conservation, vol. 16, no. 2, pp. 419-436, 2007.

[61] T. Tscharntke, Y. Clough, S. A. Bhagwat et al., "Multifunctional shade-tree management in tropical agroforestry landscapes-a review," Journal of Applied Ecology, vol. 48, no. 3, pp. 619-629, 2011.

[62] A. Albertin and P. K. R. Nair, "Farmers' perspectives on the role of shade trees in coffee production systems: an assessment from the Nicoya Peninsula, Costa Rica," Human Ecology, vol. 32, no. 4, pp. 443-463, 2004.

[63] D. Muleta, F. Assefa, S. Nemomissa, and U. Granhall, "Socioeconomic benefits of shade trees in coffee production systems in Bonga and Yayu hurumu districts, southwestern Ethiopia: farmers' perceptions," Ethiopian Journal of Education and Sciences, vol. 7, no. 1, pp. 39-55, 2011.

[64] R. Vezy, D. Deshors-Picart, M. Christina et al., "Effect of shade on temperature mitigation and canopy assimilation of coffee agroforestry systems," in Proceedings of the European Agroforestry Conference, Montpellier, France, May 2016.

[65] S. Franzel and S. J. Scherr, "Introduction," in Trees on the Farm: Assessing the Adoption Potential of Agroforestry Practices in Africa, S. Scherr and J. Franzel, Eds., Wallingford, UK, 2002. 
[66] C. D. Biggelaar and M. A. Gold, "Development of utility and location indices for classifying agroforestry species: the case of Rwanda," Agroforestry Systems, vol. 34, pp. 229-246, 1996.

[67] S. A. Bhagwat, K. J. Willis, H. J. B. Birks, and R. J. Whittaker, "Agroforestry: a refuge for tropical biodiversity?" Trends in Ecology \& Evolution, vol. 23, no. 5, pp. 261-267, 2008.

[68] I. Perfecto, I. Armbrecht, S. M. Philpott, L. Soto-Pinto, and T. V. Dietsch, "Shaded coffee and the stability of rainforest margins in northern Latin America," in Stability of Tropical Rainforest Margins, pp. 225-261, Springer, Berlin, Germany, 2007.

[69] A. D. Bote and P. C. Struik, "Effects of shade on growth, production and quality of coffee (Coffea arabica) in Ethiopia," Journal of Horticulture and Forestry, vol. 3, no. 11, pp. 336341, 2011.

[70] J. K. Kimemia, "Influence of an albizzia shade tree on soil chemical properties, coffee plant growth and yields in Kenya," in Proceedings of the 21th ASIC Proceedings, pp. 1199-1202, Montpelier, France, 2007.

[71] D. Muleta, F. Assefa, S. Nemomissa, and U. Granhall, "Distribution of arbuscular mycorrhizal fungi spores in soils of smallholder agroforestry and monocultural coffee systems in southwestern Ethiopia," Biology and Fertility of Soils, vol. 44, pp. 653-659, 2008.

[72] I. Perfecto, J. Vandermeer, A. Mas, and L. S. Pinto, "Biodiversity, yield, and shade coffee certification," Ecological Economics, vol. 54, no. 4, pp. 435-446, 2005.

[73] L. Soto-pinto, I. Perfecto, J. Castillo- Hernandez, and J. Caballero- Neito, "Shade effect on coffee production at the northern Tzeltal zone of the state chiapas Mexico," Agriculture, Ecosystems and Environment, vol. 80, pp. 61-69, 2000.

[74] J. M. Harmand, K. Hergoualc'h, S. De Miguel et al., Carbon Sequestration in Aerial Biomass and Derived Products from Coffee Agroforestry Systems in Central America, 2007.

[75] B. B. Lin, "Agroforestry management as an adaptive strategy against potential microclimate extremes in coffee agriculture," Agricultural and Forest Meteorology, vol. 144, no. 1, pp. 85-94, 2007.

[76] P. Vaast, R. Van Kanten, P. Siles et al., Shade: A Key Factor For Coffee Sustainability and Quality, ASIC, Kobe, Japan, 2005.

[77] R. Aerts, K. Hundera, G. Berecha et al., "Semi-forest coffee cultivation and the conservation of Ethiopian Afromontane rainforest fragments," Forest Ecology and Management, vol. 261, no. 6, pp. 1034-1041, 2011.

[78] K. Hundera, R. Aerts, A. Fontaine et al., "Effects of coffee management intensity on composition, structure, and regeneration status of Ethiopian moist evergreen Afromontane forests," Environmental Management, vol. 51, no. 3, pp. 801-809, 2013.

[79] C. B. Schmitt, F. Senbeta, M. Denich, H. Preisinger, and H. J. Boehmer, "Wild coffee management and plant diversity in the montane rainforest of southwestern Ethiopia," African Journal of Ecology, vol. 48, no. 1, pp. 78-86, 2010.

[80] M. M. Bos, I. Steffan-Dewenter, and T. Tscharntke, "Shade tree management affects fruit abortion, insect pests and pathogens of cacao," Agriculture, Ecosystems \& Environment, vol. 120, no. 2, pp. 201-205, 2007.

[81] G. Schroth, J. Lehmann, M. R. L. Rodrigues, and J. L. V. Barros E \&Macêdo, "Plant-soil interactions in mutistrata agroforestry in the humid tropics," Agroforestry Systems, vol. 53, pp. 85-102, 2001

[82] E. D. S. Matos, E. D. S. Mendonça, I. M. Cardoso, P. C. D. Lima, and D. Freese, "Decomposition and nutrient release of leguminous plants in coffee agroforestry systems,"
Revista Brasileira de Ciência do Solo, vol. 35, no. 1, pp. 141149, 2011.

[83] S. R. Gliessman, Agroecology: The Ecology of Sustainable Food Systems, CRC Press, Boca Raton, FL, USA, 2nd edition, 2007.

[84] R. R. Leakey, "The role of trees in agroecology and sustainable agriculture in the tropics," Annual Review of Phytopathology, vol. 52, pp. 113-133, 2014.

[85] R. C. Pincho, R. P. Miller, and S. S. Alfaia, "Agroforestry and the Improvement of soil fertility: a view from Amazonia," Applied and Environmental Soil Science, vol. 2012, Article ID 616383, 11 pages, 2012. 